Roman Bartnicki, Jezus w drodze do śmierci i zmartwychwstania. Komentarz do Ewangelii Marka 8,27-16,20. II. Mk 14,1-16,20, (Warszawa: Instytut Papieża Jana Pawła II 2019). Ss. 478. PLN 49. ISBN 978-83-65198-60-0

\title{
ŁUKASZ BIEŁUSZ
}

Sekcja Nauk Biblijnych, Katolicki Uniwersytet Lubelski Jana Pawła II e-mail: lukaszbieluszmsf@student.kul.lub ORCID: 0000-0003-4867-5210

Do rąk czytelników trafia nowość wydawnicza autorstwa ks. Romana Bartnickiego - cenionego polskiego biblisty, profesora Uniwersytetu Kardynała Stefana Wyszyńskiego i Papieskiego Wydziału Teologicznego w Warszawie, kapłana archidiecezji warszawskiej. Autor w swoich badaniach naukowych skupia się szczególnie na egzegezie i interpretacji Ewangelii synoptycznych, co znalazło wyraz w jego ponad czterystu różnorodnych publikacjach. Wieloletnie zaangażowanie na rzecz nauk biblijnych zostało docenione przez nadanie mu w $2017 \mathrm{r}$. tytułu honorowego członka Stowarzyszenia Biblistów Polskich. W historii powstania recenzowanej publikacji należy zwrócić uwagę na fakt, iż pierwotnie była ona zaplanowana jako drugi tom komentarza do Ewangelii św. Marka ukazującego się w serii Nowy Komentarz Biblijny nakładem Edycji Świętego Pawła. Tak się jednak nie stało. Dotychczas w częstochowskim wydawnictwie ukazał się pierwszy tom (do Mk 1,1-8,26) autorstwa ks. Artura Maliny - profesora Uniwersytetu Śląskiego. Z pewnością interesujące będzie zestawienie nowo powstałych komentarzy różnych autorów, stanowiących wzajemne uzupełnienie merytoryczne oraz zastosowanych metodologii.

Publikację R. Bartnickiego rozpoczyna „Skrócony spis treści” (s. 5-6), następnie "Spis treści” (s. 7-14) i „Słowo Arcybiskupa Stanisława Gądeckiego" (s. 15), który podkreślił:

Sumienność badawcza, poprawność językowa i jasność wywodów wcześniejszych prac są gwarancją wysokiego poziomu naukowego prezentowanego komentarza. Będą mogli z niego korzystać przygotowujący prace dyplomowe, zaangażowani w duszpasterstwie, osoby pragnące pogłębić formację biblijną i wszyscy zainteresowani Biblią (s. 15).

W „Przedmowie” (s. 17-20) autor wyjaśnia, że w komentarzu do drugiej Ewangelii kanonicznej zajmuje się narracją o wędrówce Jezusa i uczniów z oko- 
lic Cezareii Filipowej do Jerozolimy $(8,27-10,52)$, opowiadaniem o działalności Jezusa w Jerozolimie i Jego mową wygłoszoną na Górze Oliwnej $(11,1-13,37)$ oraz relacją z wydarzeń ostatniego tygodnia życia Jezusa - Jego męką, śmiercią na krzyżu i zmartwychwstaniem $(14,1-16,20)$. Opowiadanie o męce Jezusa jest bardzo ważną częścią drugiej Ewangelii, co rzutuje na całe przesłanie Marka. Autor kierował się tymi samymi zasadami metodologicznymi, co w pierwszej części komentarza ${ }^{1}$. Zastosowane reguły pracy wynikają z Konstytucji dogmatycznej o Objawieniu Bożym Dei verbum Soboru Watykańskiego II. Do zadań interpretatora należy rzetelna analiza tego, co hagiografowie chcieli przekazać oraz co sam Bóg przez nich objawił. Aby zrealizować ten postulat autor komentarza przeprowadza analizy filologiczne, literackie, historyczne w kontekście określonych gatunków literackich. Następnie przechodzi do odczytania teologicznego przesłania w odniesieniu do całej Biblii, uwzględniając tradycję i wiarę Kościoła. Autor podaje w „Przedmowie”, że korzystał ze słowników biblijno-filologicznych i wielkich słowników biblijno-teologicznych. Drugą płaszczyznę pracy interpretatora stanową analizy społeczno-historyczne, które pozwalają zobaczyć szereg uwarunkowań społeczno-kulturowych starożytnego świata. Na podstawie wymienionych analiz Bartnicki podejmuje się w dalszym etapie pracy nad tekstem biblijnym próby odczytania kerygmatu, czyli przesłania tekstu. Komentarz opiera się na egzegezie historyczno-krytycznej, która została wzbogacona elementami analizy narracyjnej. Schemat opracowanych perykop przedstawia się następująco: własny przekład, zagadnienia literacko-historyczne, egzegeza, kerygmat tekstu. Po „Przedmowie” autor wymienia „Wykaz skrótów” (s. 21-31) i „Transliterację" (s. 32-33).

Ponieważ omawiany komentarz do Ewangelii św. Marka stanowi kontynuację publikacji wydanej w 2018 r., stąd nie zawiera oddzielnego rozdziału, gdzie czytelnik mógłby zapoznać się z rozważaniami autora na temat właściwości literackich, struktury, autorstwa i okoliczności powstania Ewangelii św. Marka. Zainteresowani tą problematyką muszą sięgnąć do pierwszej części komentarza, do rozdziału „Wiadomości wstępne”. Zasadniczą treść stanowi rozdział piąty, który nosi tytuł „Opowiadanie o męce, śmierci i zmartwychwstaniu Jezusa (14,1-16,20)" (s. 35-429). Rozdział piąty składa się z siedemnastu paragrafów: 5.1. Wprowadzenie do opowiadania o męce; 5.2. Spisek przeciwko Jezusowi i namaszczenie w Betanii (14,1-11); 5.3. Przygotowanie posiłku paschalnego (14,12-16); 5.4. Zapowiedź zdrady jednego z Dwunastu (14,17-21); 5.5. Ustanowienie Eucharystii (14,22-25); 5.6. Przepowiednie Jezusa na Górze Oliwnej (14,26-31); 5.7. Modlitwa Jezusa w Getsemani (14,32-42); 5.8. Aresztowanie Jezusa (14,43-52); 5.9. Proces przed Sanhedrynem (14,53-65); 5.10. Zaparcie

$1 \quad$ R. Bartnicki, Jezus w drodze do śmierci i zmartwychwstania. Komentarz do Ewangelii Marka 8,27-16,20. I. $M k$ 8,27-13,37 (Warszawa : Instytut Papieża Jana Pawła II 2018). 
się Piotra (14,66-72); 5.11. Proces rzymski Jezusa (15,1-15); 5.12. Król wyszydzony przez żołnierzy $(15,16-20 a) ; 5.13$. Ukrzyżowanie i wyszydzenie Jezusa (15,20b-32); 5.14. Śmierć Jezusa na krzyżu i jej świadkowie (15,33-41); 5.15. Pogrzeb Jezusa (15,42-47); 5.16. Zmartwychwstanie (Mk 16,1-8); 5.17. Chrystofanie i wniebowstąpienie Jezusa (16,9-20). Dodatkowo objaśnieniem służą: sześć ekskursów i dwa aneksy. Ekskursy obejmują wybrane przez autora zagadnienia: 1. Geneza święta Paschy (s. 150-151); 2. Rytuał Paschy w czasach Chrystusa (s. 152-155); 3. Liturgie, obrządki i ryty (s. 156-160); 4. Namiestnicy rzymscy. Poncjusz Piłat (s. 280-281); 5. Cierpienie i gwałtowna śmierć w hellenistycznych i łacińskich biografiach (s. 325-326); 6. Współczesne badania poświęcone starożytnym ukrzyżowaniom (s. 327-331). Natomiast aneksy: 1. Problem odpowiedzialności za śmierć Jezusa (s. 412-418); 2. Chronologia opowiadań o męce (s. 419-429). Autor proponuje czytelnikowi własny przekład Ewangelii, opierając się na tekście greckim 28. wydania krytycznego Nowego Testamentu (Nestle-Aland). Sam zaznacza, że krytyce tekstu poświęca tyle miejsca, ile jest niezbędne do dalszych analiz, a warianty tekstu umieszcza w przypisach. Odnajdywaniu interesujących zagadnień oraz ich wykorzystaniu naukowemu sprzyja bardzo szczegółowy i konsekwentnie ułożony spis treści, co wynika z wieloletniego badawczego doświadczenia autora. Kolejne akapity paragrafów dotyczących egzegezy, dla ułatwienia orientacji w tekście Ewangelii, są opatrzone na marginesie siglami. Ukłonem w stronę czytelników nieznających języka greckiego jest zgodny ze współczesnymi standardami zapis słów greckich w transliteracji. Książka nie zawiera ogólnego podsumowania, ponieważ wnioski teologiczne zamieszczono na końcu poszczególnych paragrafów. Do tej części powinni sięgnąć czytelnicy zainteresowani wykorzystaniem duszpasterskim.

Całość komentarza R. Bartnickiego zamyka obszerna „Bibliografia” (s. 430-476), która obejmuje: teksty biblijne, apokryfy, papirusy, teksy z Qumran i komentarze do nich, literaturę rabiniczną, hellenistycznych pisarzy żydowskich i teksty hellenistyczne paralelne do Nowego Testamentu, teksty wczesnochrześcijańskie, dokumenty kościelne, pomoce biblijne i filologiczne, słowniki biblijno-teologiczne, komentarze nowożytne oraz monografie, książki i artykuły. Autor zaznacza, że podane pozycje nie zawsze są pierwszym lub najnowszym wydaniem, ale tym, z którego korzystał. Książka została wydana bardzo starannie. Projekt okładki był inspirowany Ewangeliarzem z Rossano, purpurowym kodeksem uncjalnym Nowego Testamentu, pochodzącym z VI wieku.

Recenzowana książka zamyka dwutomowy komentarz do Ewangelii św. Marka. Pracę należy ocenić bardzo wysoko, ponieważ autor konsekwentnie realizuje zapowiedzianą metodologię. Niniejszy komentarz pozwoli czytelnikowi zapoznać się z rzetelną egzegezą i interpretacją drugiej Ewangelii, co z pewno- 
ścią wynika z wieloletnich badań warszawskiego profesora. Adresatami opracowania R. Bartnickiego są nie tylko bibliści, ale wszyscy poszukujący wiedzy biblijnej i oczekujący pogłębienia swojej wiary. 